\title{
Antihyperlipidemic Properties of Powder Fractions and Extracts of Diospyros Mespiliformis HOCHST Fruits
}

\author{
MAI-MBE Baiva Chantal1 ${ }^{1}$, NGATCHIC Metsagang Therese Josiane $2^{2}$, NJINTANG Yanou Nicolas ${ }^{1}$ \\ ${ }^{1}$ Department of Biological Sciences, Faculty of Sciences, University of Ngaoundere, Ngaoundere, Cameroon \\ 2Department of Food Science and Nutrition, National School of Agro-industrial Science, Ngaoundere, P.O. Box 455, University of \\ Ngaoundere, Cameroon
}

*Corresponding Author

NGATCHIC Metsagang Therese Josiane

\author{
Article History \\ Received: 02.10.2019 \\ Accepted: 09.10.2019 \\ Published: 02.11.2019
}

\begin{abstract}
Hyperlipidemia is one of the major risk factors for the development of cardiovascular disease. Many bioactive compounds extracted from plants, particularly polyphenols, have demonstrated a beneficial effect on health. Obtaining these molecules requires extraction, conventional extraction techniques uses solvents whose residue affects these compounds, the environment and the health of consumers. Faced with these problems some techniques, a new axis has been developed it is the dry extraction (controlled sieving-differential spray). Diospyros mesiliformis is poorly studied regarding the bioactive compounds of its fruits. The aim of this study is to find out the optimal conditions for the dry extraction of bioactive compounds compare to solvent extraction and to study antihyperlipidemic activity of the fruit. Granulometric classes ranging from $50 \mu \mathrm{m}$ to $315 \mu \mathrm{m}$ were studied. Hydroethanolic and ethanolic extracts of Diospiros mesiliformis were analyzed for total phenolic, total flavonoid, and total tannin contents. For study of antihyperlipidemiac activity, hyperlipidemia was induced by feeding animals with high fat diet daily and orally ad libitum. Ten groups of five animals in each received normal saline, high fat diet, high fat diet plus $D$. mesiliformis powder $(600 \mathrm{mg} / \mathrm{kg})$ and extracts $(600 \mathrm{mg} / \mathrm{kg})$ body weight was given in both models and Atorvastatin $(10 \mathrm{mg} / \mathrm{kg})$ body weight was given in both models respectively for 30 days. At the end of the study, total cholesterol, triglycerides, high density lipoprotein (HDL), low density lipoprotein $(\mathrm{LDL})$, atherogenic index (Al) of rats were evaluated and were compared with the rats treated with Atorvastatin $(10 \mathrm{mg} / \mathrm{kg})$ body weight. The particle size and the extracts had high influence on the total phenolic compounds, total flavonoid and tannin content as well as on the antihyperlipidemic activity. Diospyros mespiliformis can be safely used in the treatment of mild to moderate cases of hyperlipidemia considering its easy availability, cost effectiveness, and other beneficial effects.
\end{abstract}

Keywords: Diospyros mespiliformis, dry extraction, solvent extraction, lipids, phenolic compounds.

\section{INTRODUCTION}

Hyperlipidemia is a modifiable risk factor of an important killer disease "cardiovascular diseases". It is now established that it represents a major risk factor for the premature development of atherosclerosis and its cardiovascular complications. Its prevalence is growing not only in developed countries but also in developing countries [1]. Hyperlipidemia is a condition which characterized by abnormal elevation of lipid such as (triglyceride and cholesterol) and lipoproteins such as (LDL, VLDL) levels in the blood [2]. Treatment of hyperlipidemia reduces cardiovascular events [3]. The diet enriched with saturated fats and cholesterol, contribute to the elevated lipid levels in our population as well as in many other developed countries around the world [4]. The pharmacological therapy for abnormal lipids is effective but is costly and associated with side-effects leading to patient incompliance [5]. Therefore, alternative therapies particularly, medicinal plants, legumes and fruits based are being explored, they have demonstrated a beneficial effect on health $[6,7]$. Plants constitute a source of novel chemical compounds which are of potential use in medicine and other applications. The phytochemical investigation of a plant may involve following steps: authentication and extraction of the plant material, separation and isolation of the constituents of interest, characterization of the isolated compounds and quantitative evaluation [8]. Obtaining of these bioactive molecules requires extraction. Extraction is one of the oldest known chemical operations and represents the key for the recovery and purification of active compounds from plant materials [9]. Many techniques for the extraction of bioactive compounds in medicinal plants exist. These techniques are broadly classified as conventional and non-conventional techniques. The conventional techniques include soxhlet extraction, maceration, and hydro-distillation and solvent- solvent extraction [10]. Due to the attendant

Copyright @ 2019: This is an open-access article distributed under the terms of the Creative Commons Attribution license which permits unrestricted use, distribution, and reproduction in any medium for non commercial use (NonCommercial, or CC-BY-NC) provided the original author and source are credited. 
limitations of the conventional techniques some of which include; lengthy extraction time, need for costly and high purity solvents, evaporation of the large amount of solvent, poor extraction selectivity and thermal decomposition of thermolabile compounds [11], more promising extraction techniques referred to as the nonconventional techniques were developed which include ultrasound assisted extraction, enzyme-assisted extraction, microwave-assisted extraction, pulsed electric field assisted extraction, supercritical fluid extraction and pressurized liquid extraction [12]. Recent dry method refers to drying and grinding process and extraction, it is combination of drying, grinding, and controlled sieving processes [13]. Becker et al. [14], reported that the sieving process separates plant powders by granulometric differentiation through sieves of decreasing mesh, leading to selective distribution of bioactive molecules in the different granulometric fractions.

This research work is aimed to examine the influence of powder fractions obtained by extraction techniques using grinding and sieving, and solvent extracts on total phenolic content, total flavonoid, total tannin contents and antihyperlipidemic activity of $D$. mespiliformis fruit.

\section{Materials And Methods Plant material}

The dried fruits of Diospyros mespiliformis was collected during the month of February, 2017, in Kaélé, Far-North region of Cameroon, and were transported at the laboratory of Biophysics, Food Biochemistry and Nutrition of Ngaoundere University.

\section{Preparation of ethanolic and hydroethanolic extracts of Diospyros mespiliformis fruits}

The collected fruit pulp was finely ground into powder form by using electrical grinder. The seeds were separated from the pulp using a mesh. The powder was stored in a clean air-tight plastic container at room temperature until use. About $100 \mathrm{~g}$ of the powder was weighed into $1000 \mathrm{ml}$ of ethanol $(98 \%)$ for ethanolic extracts and $100 \mathrm{~g}$ of the powder was weighed into $1000 \mathrm{ml}$ of ethanol $(50 \%)$ in the ratio $1 / 10(\mathrm{~m} / \mathrm{v})$ for hydroalcoholic extracts for 24 hours with occasional shaking. The ethanol soluble residue was filtered off and concentrated under vacuum at room temperature using a rotary evaporator to yield extract according to conventional procedure. The obtained product after evaporation was frozen in a freezer and then lyophilized using a lyophilizer.

\section{Production of powder fractions}

About $1.5 \mathrm{~kg}$ of $D$. mespiliformis fruits were slowly ground (50 g plant for each batch) with the Ultra Centrifugal Mill ZM 200 (Retsch France), operating by impact and shearing effects. Grinding was performed at room temperature (approximately $20^{\circ} \mathrm{C}$ ) using a $1 \mathrm{~mm}$ sieve with trapezoid holes. The grinding time was fixed to $2 \mathrm{~min}$. Indeed, [15], showed that concentrations of polyphenols, flavonoids and the antioxidant properties decrease when the grinding time increases. One speed was used for milling: $6000 \mathrm{rpm}$. After grinding, plant powders were sieved with the vibratory sieve shaker Analysette 3 Spartan (Fritsch, Idar-Oberstein, Germany) at 0.5 $\mathrm{mm}$ vibration amplitude for $10 \mathrm{~min}$. $20 \mathrm{~mm}$ diameter sieves (Fritsch) were employed so as to obtain the following granulometric fractions: $<50 \mu \mathrm{m} ; 50-180 \mu \mathrm{m} ; 180-315 \mu \mathrm{m} ;>315 \mu \mathrm{m}$. Powders were then stored under vacuum in sealed bags at $10^{\circ} \mathrm{C}$.

\section{Total phenolics content}

Preparation of extracts

Extraction of polyphenols from D. mespiliformis fruits were carried out according to the method of Kim et al. [16], with some modifications. $5 \mathrm{~g}$ ethanolic, hydroalcoholic extracts of dried fruits and $2 \mathrm{~g}$ of powdered dried fruits were macerated during $24 \mathrm{~h}$ under stirring, in $25 \mathrm{~mL}$ methanol/water 70/30 (v/v). Then, the methanol/water extract was centrifuged at 20,000 rpm for $20 \mathrm{~min}$. The supernatant layer was filtered, brought to $15 \mathrm{~mL}$ and stored at $4{ }^{\circ} \mathrm{C}$ before analysis.

Total phenolic compounds were determined according the protocol used by Wafa et al [17]. $20 \mu \mathrm{L}$ of samples was mixed with $500 \mu \mathrm{L}$ of Folin-Ciocalteu reagent $(1 \mathrm{~N})$ and $400 \mu \mathrm{L}$ of sodium carbonate $\left(\mathrm{Na}_{2} \mathrm{CO}_{3}, 20 \%\right)$. Samples and blank were thoroughly mixed and vortexed. After 30 min of incubation at room temperature, the absorbance was measured at $760 \mathrm{~nm}$. Total phenolic content was expressed in terms of equivalent amounts of gallic acid $(0,2 \mathrm{~g} / \mathrm{L})$ per $100 \mathrm{~g}$ of dry matter (GAE/100g DW). Absorbance measurements were carried out with UV-visible spectrophotometer.

\section{Total flavonoids content}

Total flavonoid compounds were dosed by a colorimetric assay described by Dewanto et al. [18]. $0.1 \mathrm{~mL}$ of sample were added to a volumetric flask containing $2.4 \mathrm{~mL}$ of distilled water and $0.1 \mathrm{~mL}$ of sodium nitrite $\left(\mathrm{Na}_{2} \mathrm{NO}_{2}, 5 \%\right)$ were added to the flask. After $6 \mathrm{~min}, 0.3 \mathrm{~mL}$ of aluminum chloride $\left(\mathrm{AlCl}_{3}, 10 \%\right)$ were added. After $5 \mathrm{~min}, 1 \mathrm{~mL}$ of sodium hydroxide $(\mathrm{NaOH}, 1 \mathrm{M})$ were added to the mixture. At this level the mixture was diluted with $2.5 \mathrm{~mL}$ of distilled water, then the vortexed samples were kept at room temperature. The absorbance was directly measured at $510 \mathrm{~nm}$. For use as calibration curve, diluted solutions of catechin $(0,1 \mathrm{~g} / \mathrm{L})$ were used and total flavonoids were expressed as $\mathrm{mg}$ of catechin equivalent per $100 \mathrm{~g}$ of dry matter (mg CE/100 g DM). As for Total phenolic compounds, absorbance measurements were performed with UV-visible spectrophotometer.

\section{Total tannins content}


Total tannins compounds were dosed by a colorimetric assay described by Sun et al [19]. $0.05 \mu \mathrm{L}$ of sample were added to a volumetric flask containing $3 \mathrm{~mL}$ of vanillin $(4 \%), 1.5 \mathrm{~mL}$ of sulfuric acid concentrate were added to the flask. After vortexed samples were incubate $30 \mathrm{~min}$ at room temperature, the absorbance was measured at $500 \mathrm{~nm}$. The absorbance was directly measured at 510 $\mathrm{nm}$. For use as calibration curve, diluted solutions of catechin $(0,1 \mathrm{~g} / \mathrm{L})$ were used and total tannins were expressed as mg of catechin equivalent per $100 \mathrm{~g}$ of dry matter (mg CE/100 g DM). As for Total phenolic compounds, absorbance measurements were performed with UV-visible spectrophotometer.

\section{Animals}

Healthy Wistar albino male rats weighing between $200 \mathrm{~g}$ to $300 \mathrm{~g}$ were obtained from the animal house of National School of Agro-Industrial Sciences of the University of Ngaoundere in Cameroon. The animals were kept in well-ventilated cages maintained under standard lab conditions ( $12 / 12 \mathrm{~h}$ light/dark cycle; $25 \pm 1^{\circ} \mathrm{C}, 35$ to $60 \%$ relative humidity) in the animal house of biochemistry and nutrition laboratory. The rats had access to food and allowed free access to clean fresh water in bottles ad libitum. The animals were left to acclimatize to laboratory conditions for at least two weeks before the start of the experiment.

\section{Experimental design}

Preparation of High Fat Diet for inducing Hyperlipidemia.

The High Fat Diet induced hyperlipidemia (HFD) was formulated with $300 \mathrm{~g}$ of egg yolk, $2 \mathrm{~g}$ of cholesterol, $250 \mathrm{~g}$ of coconut oil and $50 \mathrm{~g}$ of soya oil, as described by Hamlat et al. [20], with some modifications. Table 1 shows the different formulations.

Table -1: Different formulations for rats ( $\mathrm{g} / \mathrm{kg}$ of feed)

\begin{tabular}{|l|l|l|l|}
\hline Constituents & & Normal Diet & High Fat Diet \\
\hline Proteins & Fish powder & 200 & 140 \\
\hline Glucids & Corn ash & 590 & 300 \\
\hline & Sucrose & 50 & 50 \\
\hline Lipids & Coconut oil & 0 & 250 \\
\hline & Yellow egg & 0 & 300 \\
\hline & Soybean oil & 50 & 50 \\
\hline Other & Cellulose & 50 & 0 \\
\hline & Minerals & 50 & 50 \\
\hline & Vitamins & 10 & 10 \\
\hline Total & & 1000 & 1150 \\
\hline
\end{tabular}

\section{Animal study}

For the study, the animals were weighed, recorded, numbered, and randomly divided into 10 groups of five animals each.

Treatment was done at the same time as induction for 30 days between 07:00 and 10:00 $\mathrm{h}$ Group I rats were treated as the normal control received normal diet + distilled water. Groups II rats served as negative control received High Fat Diet + distilled water. Groups III rats served as positive control received High Fat Diet + atorvastatine (10 mg/kg of body weight). Group IV animals were treated orally with $D$. mespiliformis powder fraction $<50 \mu \mathrm{m}$ at a dose of $600 \mathrm{mg} / \mathrm{kg}$ of body weight in $5 \mathrm{ml}$ of sterile water. Groups $V$ animals were treated orally with $D$. mespiliformis powder fraction $50-180 \mu \mathrm{m}$ at a dose of $600 \mathrm{mg} / \mathrm{kg}$ of body weight. Groups VI animals were treated orally with $D$. mespiliformis powder fraction $180-315 \mu \mathrm{m}$ at a dose of $600 \mathrm{mg} / \mathrm{kg}$ of body weight. Groups VII animals were treated orally with $D$. mespiliformis powder fraction $>315 \mu \mathrm{m}$ at a dose of $600 \mathrm{mg} / \mathrm{kg}$ of body weight. Groups VIII animals were treated orally with $D$. mespiliformis unsieved powder at a dose of $600 \mathrm{mg} / \mathrm{kg}$ of body weight. Groups IX animals were treated orally with $D$. mespiliformis ethanolic extract at a dose of $600 \mathrm{mg} / \mathrm{kg}$ of body weight. Groups X animals were treated orally with $D$. mespiliformis hydroethanolic extract at a dose of $600 \mathrm{mg} / \mathrm{kg}$ of body weight.

On 30nd day, after overnight fasting, animals were weighed, anesthetized and dissected; the blood was collected from the neck. The serum was obtained by centrifugation of blood at $1000 \mathrm{rpm}$, for 10 minutes. The liver, kidney, stomach, heart and testis tissues of each rat were removed and weighed immediately and the ratio of organ to body weight calculated.

\section{Biochemical Parameters}

Levels of total cholesterol (TC), triglycerides (TG) and high-density lipoprotein cholesterol (HDL-C) were evaluated using enzymatic kits (HUMAN kits) according to procedure described by Richmond and Glick et al. [21, 22]. Low Density Lipoprotein (LDL) and Very Low-Density Lipoprotein (VLDL) were measured by using Friedewald's formula.

VLDL cholesterol $(\mathrm{mg} / \mathrm{dl})=\mathrm{TG} \div 5$

$\mathrm{LDL}$ cholesterol $(\mathrm{mg} / \mathrm{dl})=\mathrm{TC}-(\mathrm{HDL}+\mathrm{VLDL})$.

\section{Determination of atherogenic index (Al)}

Atherogenic index is an important measure to elucidate the anti-atherogenic index potential of a plant. Al was calculated as: $\mathrm{Al}=(\mathrm{TC}-\mathrm{HDL}-\mathrm{C}) / \mathrm{HDL}-\mathrm{C}[23]$. 


\section{Statistical Analysis}

Results were expressed as mean + S.D and all statistical comparisons were made by means of one-way ANOVA test followed analysis and $P$ - Values less than or equal to 0.05 were considered significant. Duncan's multiple ranking test was used to rank the averages. All of these analyzes were done using the Stat Graphics Plus 5.0 software and plot curves using the Excel 2010 software.

\section{Results ANd Discussion}

The first part of this study was to determine influence of particle size of dry powder fruits, and solvent extraction (ethanol and hydroethanol) on total phenolics, flavonoids, tannins.

Results are presented in Table 2; the solvent extraction concentrates more polyphenol compounds than powder fractions. the powder fractions concentrate more polyphenol compounds is fraction $<50 \mu \mathrm{m}$ after follow by $50-180 \mu \mathrm{m}$ fraction.

Table - 2: Total phenolics, flavonoids and tannins of Diospyros mespiliformis fruits

\begin{tabular}{|l|l|l|l|}
\hline Sample & $\begin{array}{l}\text { Total flavonoids } \\
\text { CE/g DW) }\end{array}$ & $\begin{array}{l}\text { Total tannins (mg CE/g } \\
\text { DW) }\end{array}$ & $\begin{array}{l}\text { Total phenolics (mg } \\
\text { GAE/g DW) }\end{array}$ \\
\hline$<50 \mu \mathrm{m}$ & $41.46 \pm 2.32^{\mathrm{d}}$ & $62.80 \pm 2.26^{\mathrm{f}}$ & $152.89 \pm 1.86^{\mathrm{e}}$ \\
\hline $100-180 \mu \mathrm{m}$ & $30.55 \pm 4.08^{\mathrm{c}}$ & $42.73 \pm 3.98^{\mathrm{d}}$ & $138.34 \pm 1.86^{\mathrm{c}}$ \\
\hline $180-315 \mu \mathrm{m}$ & $27.88 \pm 4.25^{\mathrm{b}}$ & $35.25 \pm 2.07 \mathrm{c}$ & $148.55 \pm 1.87^{\mathrm{d}}$ \\
\hline$\geq 315 \mu \mathrm{m}$ & $31.65 \pm 4.27^{\mathrm{c}}$ & $29.25 \pm 2.08^{\mathrm{a}}$ & $115.23 \pm 1.89^{\mathrm{b}}$ \\
\hline Powder & $25.79 \pm 4.30^{\mathrm{a}}$ & $32.21 \pm 4.19^{\mathrm{b}}$ & $90.20 \pm 2.56^{\mathrm{a}}$ \\
\hline Hydroethanol extracts & $43.54 \pm 2.18^{\mathrm{e}}$ & $44.73 \pm 4.25^{\mathrm{e}}$ & $160.00 \pm 1.86^{\mathrm{f}}$ \\
\hline Ethanol extracts & $56.90 \pm 9.05^{\mathrm{f}}$ & $76.42 \pm 3.319$ & $204.27 \pm 1.879$ \\
\hline
\end{tabular}

DW: dry weight; CE: catechin equivalents; GAE: gallic acid equivalents

Values in the same column with different superscripts (a to g) are significantly different $(P<0.05)$.

Total phenolic content increased when granulometry decreased from $315 \mu \mathrm{m}$ to $50 \mu \mathrm{m}$. The ethanol extract showed a highest total phenolic content $204.27 \mathrm{mg} \mathrm{GAE} / 100 \mathrm{~g} \mathrm{DW}$, which is superior than total phenolic in powder and hydroethanol extract.

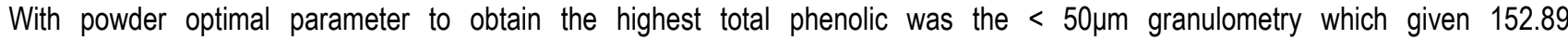
mgGAE/100gDW. Total flavonoids like the polyphenols, are distributed according to their particle sizes which in this study are

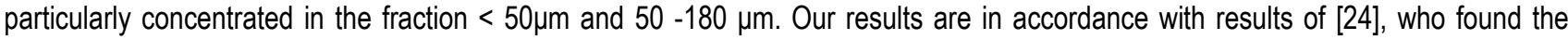
highest content of flavonoids in green tea leaves in the 100-180 $\mu \mathrm{m}$ fraction. And total tannin content followed the same tendency as total phenolics and total flavonoids.

Effect of solvents extracts and powder of Diospiros mespiliformis fruits on food intake, body weight gain/loss, organs weight, food efficiency and lipid profile high-fat diet induced

Results related to effect of $D$. mespiliformis on body weight and food intake of albino rats in different experimental groups have been provided in Table 3. After 30 days of treatment only Negative control group showed significant increasing of body weight and test groups lost. The body weight gain is due to high fat diet used to induce hyperlipidemia in the rats. High fat diet increase energy intake and energy storage [25]. The loss of body weight may be due to the ability of $D$. mespiliformis to reduce the fat absorption and lipogenic enzymes and increase the fat excretion [26]. In the present investigation, D. mespiliformis reduced the body weight gain in different groups with solvents extracts as well as with powder fractions. This may be due to the polyphenolics, flavonoids and tannins compounds, in D. mespiliformis fruits which may reduce fluid absorption and facilitate weight loss [27].

Tableau-3: Food intake and body weight gain/loss of rats

\begin{tabular}{|c|c|c|}
\hline Groups $\quad$ Parameters & $\begin{array}{l}\text { Body weight } \\
\text { gain/loss }(g)\end{array}$ & $\begin{array}{l}\text { Food intake } \\
\text { (g) }\end{array}$ \\
\hline Negative control & $13.14 \pm 2.85^{d}$ & $200.01 \pm 4.80^{a}$ \\
\hline Normal control & $0.49 \pm 2.94 c$ & $198.89 \pm 4.85^{a}$ \\
\hline Positive control & $-4.02 \pm 2.95^{b c}$ & $194.02 \pm 4.84^{a}$ \\
\hline$<50 \mu \mathrm{m}$ & $-14.23 \pm 2.89^{a}$ & $190.41 \pm 4.82^{a}$ \\
\hline $50-180 \mu m$ & $-8.77 \pm 2.95^{\mathrm{ab}}$ & $189.82 \pm 4.80^{a}$ \\
\hline $180-315 \mu \mathrm{m}$ & $-3.58 \pm 2.88 b c$ & $193.40 \pm 4.86^{a}$ \\
\hline$>315 \mu \mathrm{m}$ & $-1.05 \pm 2.95^{b c}$ & $196.27 \pm 4.83^{a}$ \\
\hline Unsieved powder & $-1.0 \pm 2.92^{b c}$ & $190.42 \pm 4.82^{a}$ \\
\hline Hydroathanolic extract & $-8.40 \pm 2.94^{a b}$ & $196.60 \pm 4.81^{a}$ \\
\hline Ethanolic extract & $-8.76 \pm 2.90 a b$ & $196.79 \pm 4.85^{a}$ \\
\hline
\end{tabular}

Values in the same column with different superscripts (a to d) are significantly different $(P<0.05)$. 
Organ-to-body weight ratios of the rats after administration of the $D$. mespiliformis extracts and powder fractions are presented in Table 4. Decrease of organ-to-body weight ratios indicating a hyper functioning of that organ; increase in the weight may be due to it degenerative changes or loss of tissue of that particular organ [28]. The organ-to-body weight ratios of liver, heart, kidney, stomach and testis of all test groups were significantly upper to those of negative control group and no different to those of normal and positive control.

Table-4: Organ-to-body weight ratios in rats after oral administration of extracts and powder fractions of $D$. mespiliformis fruits

\begin{tabular}{|c|c|c|c|c|c|}
\hline $\begin{array}{c}\text { Organs } \\
\text { Groups }\end{array}$ & Heart & Liver & Kidney & Stomach & Testis \\
\hline Negative control & $0.43 \pm 0.004^{\mathrm{e}}$ & $4.38 \pm 0.007^{\mathrm{e}}$ & $0,84 \pm 0,003^{\mathrm{i}}$ & $0.92 \pm 0.003^{\mathrm{f}}$ & $1.04 \pm 0.060^{\mathrm{b}}$ \\
\hline Positive control & $0.30 \pm 0.008^{\mathrm{bc}}$ & $3.25 \pm 0.003^{\mathrm{bcd}}$ & $0,52 \pm 0,006^{\mathrm{bc}}$ & $0.62 \pm 0.004^{\mathrm{ab}}$ & $1.10 \pm 0.006^{\mathrm{bc}}$ \\
\hline Normal control & $0.29 \pm 0.004^{\mathrm{b}}$ & $3.35 \pm 0.003^{\mathrm{bcd}}$ & $0,50 \pm 0,002^{\mathrm{a}}$ & $0.58 \pm 0.000^{\mathrm{a}}$ & $1.14 \pm 0.006^{\mathrm{bc}}$ \\
\hline$<50 \mu \mathrm{m}$ & $0.30 \pm 0.019^{\mathrm{bc}}$ & $3.58 \pm 0.054^{\mathrm{cd}}$ & $0,52 \pm 0,003^{\mathrm{abc}}$ & $0.64 \pm 0.040^{\mathrm{bc}}$ & $1.04 \pm 0.040^{\mathrm{b}}$ \\
\hline $50-180 \mu \mathrm{m}$ & $0.30 \pm 0.002^{\mathrm{b}}$ & $3.14 \pm 0.019^{\mathrm{bc}}$ & $0,55 \pm 0,005^{\mathrm{bc}}$ & $0.67 \pm 0.002^{\mathrm{bc}}$ & $0.88 \pm 0.009^{\mathrm{a}}$ \\
\hline $180-315 \mu \mathrm{m}$ & $0.31 \pm 0.004^{\mathrm{cd}}$ & $3.05 \pm 0.013^{\mathrm{b}}$ & $0,57 \pm 0,020^{\mathrm{cd}}$ & $0.69 \pm 0.030^{\mathrm{bc}}$ & $1.10 \pm 0.009^{\mathrm{bc}}$ \\
\hline$>315 \mu \mathrm{m}$ & $0.30 \pm 0.011^{\mathrm{b}}$ & $2.42 \pm 0.024^{\mathrm{a}}$ & $0,60 \pm 0,025^{\mathrm{de}}$ & $0.67 \pm 0.012^{\mathrm{c}}$ & $0.84 \pm 0.004^{\mathrm{a}}$ \\
\hline Unsieved powder & $0.36 \pm 0.003^{\mathrm{d}}$ & $3.21 \pm 0.050^{\mathrm{bcd}}$ & $0,71 \pm 0,006^{\mathrm{gh}}$ & $0.81 \pm 0.014^{\mathrm{e}}$ & $1.05 \pm 0.047^{\mathrm{b}}$ \\
\hline $\begin{array}{c}\text { Hydroethanolic } \\
\text { extract }\end{array}$ & $0.24 \pm 0.005^{\mathrm{a}}$ & $3.55 \pm 0.575^{\mathrm{cd}}$ & $0,72 \pm 0,046^{\mathrm{h}}$ & $0.74 \pm 0.042^{\mathrm{d}}$ & $1.18 \pm 0.112^{\mathrm{c}}$ \\
\hline Ethanolic extract & $0.32 \pm 0.003^{\mathrm{c}}$ & $3.60 \pm 0.263^{\mathrm{d}}$ & $0,67 \pm 0,003^{\mathrm{fg}}$ & $0.73 \pm 0.000^{\mathrm{d}}$ & $1.11 \pm 0.100^{\mathrm{bc}}$ \\
\hline
\end{tabular}

Values in the same column with different superscripts (a to g) are significantly different $(P<0.05)$.

The results of the effect of solvents extracts and powder fractions of $D$. mespiliformis fruits on lipid profile of rats are summarized in Table 5. It was seen that, there was a significant increase in all the lipid parameters $(p<0.05)$, except HDL- C, following administration of high fat diet. It is well known that diet plays an important role in the control of cholesterol homeostasis. The consumption of cholesterol-enriched diet is regarded as an important factor in the development of cardiovascular diseases as it leads to the development of hyperlipidemia, atherosclerosis and abnormal lipid oxidation/metabolism [29, 30]. The hypolipidemic activity of the groups taken extracts or powder fractions of $D$. mespiliformis was found to be slightly less efficacious than that of the standard drug but compared to the negative control group, their total cholesterol, triglyceride, LDL- C and VLDL- C are significantly low and their HDL-c higher. Hypolipidemic properties of $D$. mespiliformis may be explain by their polyphenols, in fact, polyphenols induce metabolic hypolipidemic effect mainly by their ability to reduce cholesterol acyltransferase and HMG-CoA reductase activities [3].

Table-5: Effect of powder fractions and extract of $D$. mespilifomis fruits on serum lipide profile

\begin{tabular}{|l|l|l|l|l|l|}
\hline \multicolumn{1}{|c|}{ Parameters } & TC & HDL- C & TG & \multicolumn{1}{|c|}{ LDL- C } & VLDL- C \\
\hline Negative control & $173.93 \pm 3.20^{\mathrm{e}}$ & $20.9 \pm 0.31^{\mathrm{a}}$ & $145.79 \pm 7.67^{\mathrm{d}}$ & $125.17 \pm 3.20^{\mathrm{g}}$ & $29.16 \pm 1.54^{\mathrm{d}}$ \\
\hline Positive control & $101.47 \pm 1.77^{\mathrm{bcd}}$ & $47.65 \pm 1.34^{\mathrm{f}}$ & $72.55 \pm 1.51^{\mathrm{a}}$ & $39.31 \pm 0.73^{\mathrm{b}}$ & $14.51 \pm 0.30^{\mathrm{a}}$ \\
\hline Normal control & $82.22 \pm 0.32^{\mathrm{a}}$ & $41.42 \pm 1.90^{\mathrm{e}}$ & $78.84 \pm 9.53^{\mathrm{ab}}$ & $25.03 \pm 0.31^{\mathrm{a}}$ & $15.75 \pm 1.91^{\mathrm{ab}}$ \\
\hline$<50 \mu \mathrm{m}$ & $94.99 \pm 1.34^{\mathrm{b}}$ & $25.01 \pm 0.31^{\mathrm{b}}$ & $66.0 \pm 0.07^{\mathrm{a}}$ & $56.79 \pm 1.01^{\mathrm{c}}$ & $13.2 \pm 0.01^{\mathrm{a}}$ \\
\hline $50-180 \mu \mathrm{m}$ & $101.87 \pm 0.95^{\mathrm{bcd}}$ & $27.86 \pm 0.62^{\mathrm{bcd}}$ & $74.44 \pm 6.18^{\mathrm{a}}$ & $59.13 \pm 0.92^{\mathrm{cd}}$ & $14.89 \pm 1.23^{\mathrm{a}}$ \\
\hline $180-315 \mu \mathrm{m}$ & $107.95 \pm 3.19^{\mathrm{cd}}$ & $27.86 \pm 1.36^{\mathrm{bcd}}$ & $93.16 \pm 6.13^{\mathrm{bc}}$ & $61.46 \pm 0.61^{\mathrm{de}}$ & $18.63 \pm 1.23^{\mathrm{bc}}$ \\
\hline$\geq 315 \mu \mathrm{m}$ & $110.50 \pm 3.52^{\mathrm{d}}$ & $29.79 \pm 1.52^{\mathrm{d}}$ & $103.53 \pm 17.36^{\mathrm{c}}$ & $64.0 \pm 1.45^{\mathrm{e}}$ & $19.70 \pm 2.06^{\mathrm{c}}$ \\
\hline Unsieved powder & $98.61 \pm 11.73^{\mathrm{bc}}$ & $28.31 \pm 2.24^{\mathrm{cd}}$ & $77.57 \pm 8.92^{\mathrm{ab}}$ & $61.18 \pm 1.34^{\mathrm{de}}$ & $15.51 \pm 1.78^{\mathrm{a}}$ \\
\hline Hydroethanolic extract & $108.50 \pm 2.57^{\mathrm{d}}$ & $25.86 \pm 1.58^{\mathrm{bc}}$ & $100.30 \pm 3.92^{\mathrm{c}}$ & $62.58 \pm 1.77^{\mathrm{e}}$ & $20.07 \pm 0.79^{\mathrm{c}}$ \\
\hline Ethanol extract & $109.75 \pm 1.48^{\mathrm{d}}$ & $29.92 \pm 0.12^{\mathrm{d}}$ & $97.24 \pm 2.47^{\mathrm{c}}$ & $60.38 \pm 0.86^{\mathrm{de}}$ & $19.45 \pm 0.50^{\mathrm{c}}$ \\
\hline
\end{tabular}

TC: total cholesterol; HDL-C: HDL-cholesterol; LDL-C: LDL-cholesterol; TG: triglycerides;

Values in the same column with different superscripts (a to g) are significantly different $(P<0.05)$.

Table 6 shows the atherogenic index of rats. Oral administration of extracts and powder fractions prevented the rise of atherogenic index, the fractions powder $>50 \mu \mathrm{m}, 50-180 \mu \mathrm{m}$ and solvent extracts showed strong effect. High cholesterol diet with cholic acid increases TC, LDL-C, atherogenic index and decrease HDL-C by enhancing intestinal absorption and secretion and decreasing catabolism of cholesterol [31]. Treatment with extracts and powder fractions of D. mespilifomis caused a significant decrease in mean serum TC and LDL-C and increased HDL-C, the consequence is decreasing of atherogenic index, which is considered as better indicator of coronary heart disease risk than individual lipoprotein concentration [32]. 
Table -6: Effect of powder fractions and extract of $D$. mespilifomis fruits on atherogenic index

\begin{tabular}{|c|c|}
\hline Groups & Atherogenic index \\
\hline Negative control & $7.32 \pm 0,02^{\mathrm{e}}$ \\
\hline Positive control & $1.13 \pm 0,02^{\mathrm{a}}$ \\
\hline Normal control & $0.99 \pm 0,09^{\mathrm{a}}$ \\
\hline$<50 \mu \mathrm{m}$ & $2.79 \pm 0,01^{\mathrm{b}}$ \\
\hline $50-180 \mu \mathrm{m}$ & $2.66 \pm 0,05^{\mathrm{b}}$ \\
\hline $180-315 \mu \mathrm{m}$ & $2.87 \pm 0,07^{\mathrm{b}}$ \\
\hline$\geq 315 \mu \mathrm{m}$ & $3.12 \pm 0,00^{\mathrm{c}}$ \\
\hline Unsieved owder & $2.71 \pm 0,20^{\mathrm{c}}$ \\
\hline hydroalcoholic extracts & $3.20 \pm 0,15^{\mathrm{b}}$ \\
\hline Ethanol extracts & $2.67 \pm 0,03^{\mathrm{c}}$ \\
\hline
\end{tabular}

Values in the same column with different superscripts (a to $c$ ) are significantly different $(P<0.05)$

\section{CONCLUSION}

These results revealed that polyphenols compounds and antihyperlipidemia activity depend on powder fractions and the solvent extract. Diospyros mespiliformis can be safely used in the treatment of mild to moderate cases of hyperlipidemia considering its availability, cost effectiveness, and other beneficial effects.

\section{REFERENCE}

1. Paccaud, F., Fasmeye, V. S., Wietlisbach V. \& Bovet, P. (2000). Dyslipidemia and abdominal obesity: an assessment in three general populations. Journal of Clinical Epidemiology, 53(4):393-400.

2. Tilak, K. S., Veeraiah, K., \& Koteswara, R. D. K. (2001). Restoration on tissue antioxidants by fenugreek seeds (Trigonella Foenum Graecum) in alloxan-diabetic rats. Indian Journal of Physiology and Pharmacological, 45:408-420.

3. Ballantyne, C.M. (2007). Treatment of Dyslipidemia to Reduce Cardiovascular Risk in Patients with Multiple Risk Factors. Clinical Cornerstone, 8(6): S6-S13.

4. Kourounakis, A. P., Victoratos, P., Peroulis, N., Stefanou, N., Yiangou, M., \& Hadjipetrou, L. (2002). Experimental hyperlipidemia and the effect of NSAIDs. Experimental and Molecular Pathology, 73: 135-140.

5. Grundy, S. M., Cleeman, J. I., Merz, C. N., Brewer, H. B., Clark, L. T., Hunninghake, D. B., Pasternak, R. C., Smith, S. C. \& Stone, N. J. (2004). National Heart, Lung, and Blood Institute; American College of Cardiology Foundation; American Heart Association. Implications of recent clinical trials for the National Cholesterol Education Program Adult Treatment Panel III guidelines. Circulation, $110(2):$ 227-239.

6. Rates, M. (2001). Plants as source of drugs, Toxicon Off. Journal of International Society Toxicology. 39.

7. Braithwaite, M., Tyagi, C., Tomar, K., Kumar, P., Choonara, E. \& Pillay V. (2014). Nutraceutical-complement modern medicine. An overview Journal of Functional Foods. 6 82-99.

8. Evans, W. C. (2008). General methods associated with the phytochemical investigation of herbal products. In Trease and Evans Pharmacognosy (15 ed.), New Delhi: Saunders (Elsevier),137-148.

9. Wang, X.Q., Wei, F.Y., Wei, Z.F., Zhang, L., Luo, M., Zhang, Y.H., (2014).Homogenate-assisted negative-pressure cavitation extraction for determination of organic acids and flavonoids in honeysuckle (Lonicera japonica Thunb.) by LCeMS/MS. Separation and Purification Technology, 135, 80-87.

10. Penchev, I. (2010). Étude des procédés d'extraction et de purification de produits bioactifs à partir de plantes par couplage de techniques séparatives à basses et hautes pressions Thèse de Doctorat, Institut National Polytechnique de Toulouse, France.

11. Luque de Castro, M. D. \& Garcia-Ayuso, L. E. (1998). Soxhlet extraction of solid materials: an outdated technique with a promising innovative future. Analytical and Chimical Acta, 369 (1-2): 1-10.

12. Azmir, J., Zaidul, I. S. M., Rahman, A. M. M. Sharif, K. M., Mohamed, A., Sahena, F., Jahurul, M. H. A., Ghafoor, K., Norulaini, N. A. N. \& Omar, A. K. M. (2013). Techniques for extraction of bioactive compounds from plant materials: A review. Journal of Food Engineering, 117. 426-436.

13. Baudelaire, E. (2013). Brevet WO2013057379A1 - Procédé Ptc Pour l'extraction Par Voie Sèche Des Principes Actifs Naturels. GoogleBrevets http: //www.google.com /patents/ W02013057379A1. cl=fr.

14. Becker, L., Zaiter, A., Petit, J., Karam, M. C., Sudol, M., Baudelaire, E., \& Dicko, A. (2017). How do grinding and sieving impact on physicochemical properties, polyphenol content, and antioxidant activity of Hieracium pilosella L. powders. Journal of Functional Foods, 35, 666- 672. https://doi.org/10.1016/j.jff.2017.06.043

15. Hu, J., Chen, Y., \& Ni, D. (2012). Effect of superfine grinding on quality and antioxidant property of fine green tea powders. LWTFood Science and Technology, 45, 8-12.

16. Cuji'c, N., Savikin, K., Jankovi'cT, Pljevljakusi'c, D., Zduni'c \& G Ibri'c, S. ( 2015). Optimization of polyphenols extraction from dried chokeberry usingmaceration as traditional technique. Food Chemistry. 194: 135-142,http://dx.doi.org/10.1016/j.foodche.

17. Wafa, G., Amadou, D., Larbi, M. \& Héla, O. (2014). Larvicidal activity, phytochemical composition,and antioxidant properties of different parts offive populations of Ricinus communis Leading Indian Cro. Pro. 56: 43-51. 
18. Dewanto, V., Wu, X., Adom, K. K. \& Liu, R. H. (2002). Thermal processing enhances the nutritional value of tomatoes by increasing total antioxidant activity. Journal of Agricultural and Food Chemistry, 50: 3010-3014.

19. Sun, B. S., Ricardo-Da-Silva, J. M. \& Spranger, M. I. (2008). Critical factors of vanillin assay for catechins and proanthocyanidins. Journal of Agricultural and Food Chemistry, 107(10), 4267-4274.

20. Hamlat, N., Neggazi, S., Benazzoug, Y., Kacimi, G., Chaïb, S., \& Aouichat-Bouguerra, S. (2008). Régime hyperlipidique et processus athéroscléreux chez Rattus norvegicus. Sciences \& Technologie. C, Biotechnologies, (27), 49-56.

21. Richmond, W. (1973). Medical analysis. Clinical Chemistry, 19, p. 1350.

22. Glick, M. R., Ryder, K. W., \& Jackson, S. A. (1986). Graphical comparisons of interferences in clinical chemistry instrumentation. Clinical Chemistry, 32(3), 470-475.

23. Makni, M., Fetoui, H., Gargouri, N. K., Garoui, E. M., Jaber, H., Makni, J., ... \& Zeghal, N. (2008). Hypolipidemic and hepatoprotective effects of flax and pumpkin seed mixture rich in $\omega-3$ and $\omega-6$ fatty acids in hypercholesterolemic rats. Food and Chemical Toxicology, 46(12), 3714-3720.

24. Becker, L., Zaiter, A., Petit, J., Karam, M. C., Sudol, M., Baudelaire, E., ... \& Dicko, A. (2017). How do grinding and sieving impact on physicochemical properties, polyphenol content, and antioxidant activity of Hieracium pilosella L. powders?. Journal of Functional Foods, 35, 666-672.

25. Onyeike, E. N., Monanu, M. O., \& Okoye, C. N. (2012). Changes in the blood lipid profile of wistar albino rats fed rich cholesterol diet.

26. Rains, T. M., Agarwal, S. \& Maki, K. C. (2011). Antiobesity effects of green tea catechins: a mechanistic review. Journal of Nutrition and Biochemistry, 22:1-7.

27. Amin, K. A., \& Nagy, M. A. (2009). Effect of carnitine and herbal mixture extract on obesity induced by high fat diet in rats. Diabetic and Metabolic Syndrome Journal, 1: 1-17.

28. Raza, M., Al-shabanah, O., El-Hadiyah, T. \& Al-Majed, A. (2002). Effect of prolonged vigabatrin treatment on hematological and biochemical parameters in plasma, liver and kidney of swiss albino mice. Scientia pharmaceutical, 70:135-145.

29. Onody, A. M., Csonka, C., Giricz, Z. \& Ferdinandy, P. (2003). Hyperlipidemia induced by a cholesterol-rich diet leads to enhanced peroxynitrite formation in rat hearts. Cardiovascular Research, 58: 663-670.

30. Rajasekaran, A., Vellaichamy, S. \& Sabarimuthu, D. (2011). Effect of Blepharis maderaspatensis L. Roth. Extracts on serum lipids in Triton WR-1339 and high cholesterol diet induced hyperlipidemia in rats. African Journal of Pharmacy and Pharmacology, 7(37), pp. 2577-2583, 8.

31. Heuman, D. M., Vlahcevic, Z. R., Bailey, M. L. \& Hylemon, P. B. (1988). Regulation of bile acid synthesis. II. Effect of bile acid feeding on enzymes regulating hepatic cholesterol and bile acid synthesis in the rat. Hepatology, (4):892-897.

32. Vijayakumar, R. S., Surya, D. \& Nalini, N (2004). Antioxidant efficacy of black pepper (Piper nigrum L.) and piperine in rats with high fat diet induced oxidative stress. Redox Rep, 9(2):105-110. 